\section{Ratomir Antonović ${ }^{1}$}

University Union "Nikola Tesla" Belgrade

Faculty of Law, Security and Management

"Konstantin Veliki"

Miloš Krstić ${ }^{2}$

University of Niš

Faculty of Natural Sciences and Mathematics
SCIENTIFIC REVIEW ARTICLE doi:10.5937/ekonomika1902109A

Received: March, 12, 2019

Accepted: Jun, 09, 2019

\title{
SOCIAL PROTECTION RIGHTS IN THE CONTEXT OF NEW LEGISLATIVE SOLUTIONS IN THE REPUBLIC OF SERBIA
}

\begin{abstract}
The Law on Social Protection of the Republic of Serbia was adopted in 2011 and contains solutions resulting from the reform processes in this field. This Act sought to ensure: the minimum material security of individuals and families, the availability of social assistance services, to guarantee equal conditions for the individual's individual life, to upgrade and improve family relationships, as well as to prevent unwanted occurrences such as: abuse, neglect and exploitation of people. However, despite the reform intentions and the achieved results in this area, during seven years of application of this law, numerous defects and shortcomings were noted, and there was a need for the adoption of the Law on Amendments to the Law on Social Protection. Since the issue of amending the positive Law on Social Protection is actual issue, the measures that were proposed by the respective amendments and proposals were analyzed, with a review of positive legal solutions, as well as the potential effects that could be achieved by adopting the proposed changes. All changes are aimed at the social protection in the Republic of Serbia is raised to a higher level, in order to bring the position of the user to an adequate level, respecting his personality and integrity. On the other hand, one of the major novelties is certainly social activation of social assistance beneficiaries, which in practice means that each user will be engaged in work according to his abilities and ability to work. This novelty is not in an antagonism with the basic goal of social protection, that is material support and the provision of social care services, because the working engagement of social welfare beneficiaries only stimulates their working capacity and performs vocational and professional training, that leads to integration into society as equal community members. So, although disputed, this novelty cannot be harmful to the users, because it gives them multiple opportunities, through job training, through social integration.
\end{abstract}

Key words: social assistance, protection, family, human rights, social welfare center

JEL classification: $K 15$

\footnotetext{
${ }^{1}$ antonovicr@gmail.com

22krsticmilo3@gmail.com
} 


\title{
ПРАВО НА СОЦИЈАЛНУ ЗАШТИТУ У КОНТЕКСТУ НОВИХ ЗАКОНСКИХ РЕШЕЫА У РЕПУБЛИЦИ СРБИЈИ
}

\begin{abstract}
Апстракт
Закон о соиијалној заштити Републике Србије је донесен 2011.године и садржи решења која су резултат реформских процеса у овој области. Овим Законом се настојало обезбедити минимум материјалне сигурности појединаца и породица, доступност услуга из области социјалне помоћи, гарантовати једнаке услове за самостални живот сваког појединиа, надограђивати и усавршавати породичне односе, као и предупредити нежељене појаве као ито су злостављање, занемаривање и експлоатација људи. Међутим, упркос реформским интенцијама и постигнутим резултатима у овој области, током седмогодишье примене овог закона, уочене су бројне мане и недостаци, те се указала потреба за доношенем Закона о изменама и допунама закона о сочијалној заштити. Како је актуелно питање измена и допуне позитивног Закона о сочијалној заштити, анализиране су мере које су предметним изменама и сопунама предложене, уз осврт на позитивна законска решења, као и потенцијалне ефекте који би се могли остварити усвајањем предложених измена. Све промене иду ка томе да се социјална заштита у Републици Србији подигне на виши ниво, да се положај корисника доведе на адекватно место, уз уважавање юегове личности и његовог интегритета. Са друге стране, једна од великих новина свакако представља радна активација корисника социјалне помоћи, што у пракси значи да ће сваки корисник бити радно ангажован складно својим могућностима и радној способности. Ова новина није у антагонизму са основним цииљем сочијалне заштите, а то је материјална подрика и пружање услуге соиијалне заштите, јер се радним ангажовањем корисника сочијалне помоћи само подстиче юихов радни капащитет и врши радно и стручно оспособљавање, што ин води ка интеграцији у друштво као равноправних чланова заједнице. Тако да, иако оспоравана, ова новина не може бити штетна по кориснике, јер им даје вишеструке могућности, што кроз радно оспособљавање, ито кроз социјалну интеграцију.
\end{abstract}

Кључне речи: сочијлана помоћ, заштита, породица, људкса права, цчентар за сочијални рад

\section{Introduction}

Social protection could be defined as a series of measures by which state institutions provide assistance to socially vulnerable categories of the population. The goal of social protection is to improve the financial situation, opportunities for employment and health care, as well as all other vital aspects of the social life of socially vulnerable citizens of a state. These measures are primarily entrusted to the state, that is, the society, and therefore they have the attribute "social", and they are reflected in the help and support of the socially vulnerable. Because of this, the general and commonly used name for them in most modern legislation is social assistance, social welfare, social support or 
social welfare. In addition, in a large number of modern countries, besides the state, in providing social assistance, NGOs also took part, providing professional assistance to all or certain of the categories of socially vulnerable citizens.

Social protection can be provided in a number of different ways, through: providing social assistance, providing food and grocery products, providing hygienic and other packages, social housing construction and awarding solidarity apartments and health care and care and other similar ways (Radovanović, 2015, p. 16-17). Social welfare beneficiaries are socially vulnerable categories of the population: unemployed, severely ill and persons with disabilities, elderly persons who have no one to worry about, multifamily families with many children, participants in wars and other persons whose existence is endangered. Based on the volume of social assistance, i.e. how many people can enjoy social assistance, the classification of countries that are socially responsible and those that are not. It is considered that countries where a wide range of social assistance is represented by socially responsible countries, that adequately care for their socially vulnerable citizens, while countries that selectively provide social assistance do not have the character of socially responsible countries. Of course, the volume of social assistance beneficiaries is conditioned by the economic possibilities of the given country, and that richer countries are also socially responsible.

Social protection in the Republic of Serbia is based on material benefits and social protection services. It also includes child protection and pension and disability insurance. Material benefits are material assistance that is assigned (granted) to socially vulnerable categories of people. Beneficiaries of material benefits may be permanent and occasional. Permanent users are people who are permanently disabled to provide the means for their lives, and social assistance is their only source of income. Occasional users are persons who have been temporarily unable to provide funds for their own lives, most often as a result of an unfortunate situation or natural disaster (earthquake, flood, fire, storm, etc.). Social protection services include the assessment and planning of direct social work services arising from the assessment of the needs of social service users. They consist of daily community services, support in independent life, counseling - therapeutic and social - educational services, as well as accommodation services. Daily services can be provided in the living rooms, and can be in the form of home help, support for independent life includes support services, personal assistance and training for independent living. Advisory - therapeutic and social-educational services consist of family counseling, counseling of vulnerable persons, family therapies, mediations and organization of emergency telephone lines. Accommodation services include the accommodation of vulnerable persons in reception centers, where food, medical assistance and care are provided. The accommodation is done at reception centers, shelters and reception stations.

\section{New social policy measures in Serbia}

Positive Law on Social Protection of the Republic of Serbia (Official Gazette RS No. 24/2011) was adopted in 2011 in the process of reforming the social protection system in our country, that brought about the introduction of modern solutions and numerous innovation in comparison with the previous social policy that was in force in our country. 
As one of the essential novelties, it is definitely considered the introduction of measure of accommodation in the home as a form of social support. New measures concerned the provision of protection within the community itself and the environment of the person to whom social protection is provided. Also, the principle of decentralization of the provision of social assistance was adopted, which practically meant lowering it from the level of the republic to the level of bodies of the provinces and local self-government units. Then, pluralism of social service providers was introduced, where besides public organizations, a number of private organizations from the non-governmental sector are involved in the process of providing social services. For the first time, quality system was introduced, that included the standardization of social care services, the accreditation of training programs for staff development, and the provision of services and professional assistance.

In addition to all the innovative solutions introduced by this law in practice, certain shortcomings and inconsistencies that prevent the achievement of the expected effects of the legal act were also noticed during its implementation. Also, at the time of the application of the positive Law on Social Protection, there have been changes in some of the Laws that are applied in the application of its provisions. Finally, it was noted that some proposed legal solutions did not yield the desired results. Therefore, in line with European legal solutions in this matter, a number of measures for amendments to the Law on Social Protection are designed. These measures are reflected in better allocation of resources in order to provide support to able-bodied social assistance beneficiaries in cooperation with the National Employment Service. Then, through incentive measures to local self-governments, especially poorer, to develop services through dedicated transfers from the national level. It also insists on: 1) the modernization of housing facilities, especially housing facilities for persons with disabilities, and 2) better monitoring and evaluation, and the strengthening of control mechanisms. The work on the information interconnection of various social and state sectors is particularly important because it eliminates administrative obstacles to social assistance beneficiaries with a considerable shortening of the deadline for exercising their rights, thus increasing the efficiency of the work of the social assistance authorities in the Republic of Serbia. Centers for Social Work across the country will be able to act through the centralized information system on requests (applications) for recognition of the right to assistance, for reviewing the evidence of other state authorities, and will be given the opportunity to collect autonomous evidence which saving time and raising the level of efficiency.

The general goals of the new measures of social policy in the Republic of Serbia are: 1) the improvement of the quality of services and the implementation of professional procedures in the field of social protection, 2) the improvement of the quality of providing social protection to persons at the level of local self-governments, 3) the elimination of legal and technical shortcomings present in the positive Law on social assistance, especially in the area of prevention of displacement of the child from the family, 4) the raising the level of competences of employed persons in the centers for social work and other bodies dealing with social policy in the state, 5) the building mechanisms for control, monitoring and evaluation of the social welfare system protection and legal harmonization of new legal solutions with other relevant laws at the level of the Republic of Serbia (Brković, 2014, p. 199-210). 


\section{Expectations from new measures}

The basic starting point for the drafting of the Law on Amendments to the Law on Social Assistance is the the improvement and modernization of the existing social protection system that exists in the Republic of Serbia. The current work of social welfare institutions in our country has proven to be insufficiently efficient and consistent to meet all the challenges ahead they set him up. The new measures will, first of all, seek to ensure quality in the work of social assistance institutions. In practice that was previously represented and to which social assistance beneficiaries often had many objections, the Centers for Social Work, as a public service, whose founder of local self-government units, were the main and primary providers of social assistance. The changes to the Centers for Social Work significantly narrow the competencies to the assessment and planning segment. Apart from the narrowing of competence of CSWs ensures (to ensure) better quality of services provided, the existence of conflicts of interest due to interferences of competencies, which were inevitable, is prevented. Several different service activities were conducted in the centers for social work, that were often interference, which had a conflict of jurisdiction for the final result. Such situations were due to the fact that the centers performed the tasks delegated by the founders, that is, the units of local selfgovernment from one hand, while on the other hand they performed tasks delegated by the republican institutions. Thus, the centers received overwhelming responsibilities with a large amount of work, that could not be completed either efficiently or quality. They are far from their primary jurisdiction, which, in the end, had the worst reflection for social assistance to users. The basis for this burden on social welfare centers lies in the provision of positive law that states that the Center for Social Work can provide other social welfare services if there is no adequate provider of these services. Therefore, with this formulation, an integral part of the work that does not belong to any other state body is in the corpus of the competence of the Center for Social Work, and because of its character, it should be left to the center.

When drafting new legal measures, the legislator proceeded from the fact that in our country there has been increased number of procedures in the field of family legal protection and an increased number of children who are placed in foster families. This is an absolute sign of weakening the authority of the institution of the family, that is becoming less and less appreciated, not only in our country, but globally. Therefore, the need for strengthening family support mechanisms, strengthening family capacities, the role of parents and parenthood is obvious, with the aim of better and more adequate care and protection for children. The foster care measure, that is highly represented, applies to children without parental care or to children whose parents have psycho-physical developmental disorders, behavioral disorders, and consequently the child cannot live with the parent. A family of fathers has the role of providing the child with all the necessary conditions in accordance with the law and his special needs conditioned by his age and health status. A nutritionist represents a temporary or permanent substitution to a parent, and it is therefore clear how important his role is to the child in the foster family. The furnishings can be standard when the needs of a child with proper psycho-physical development is met, for which it is estimated that foster care is in his best interests. Such fostering may take longer or shorter periods of time. Specialized fostering meets the needs of the child with psychological and physical developmental disorders, with 
health problems and behavioral disorders. As a rule, this kind of fostering takes a longer period of time. Urgent fostering is caused by the child's abandonment by a parent, gross neglect or abuse, or when the parent's death occurs. This fostering lasts until the crisis in the family is resolved. At the end, there is occasional fostering for the children with developmental or health problems, that (and) live in their biological families. Children are placed on the occasional foster care for a short period of time in order to preserve the capacity of the biological family for further child care and in order to prevent the crisis situations that can endanger the capacity of the biological family (Nedeljković, 2017, p. 25-31).

The effect of the new measures proposed in the context of the above, should be reflected in the strengthening of family capacities with the aim of preventing the relocation of children from their biological families. The opinion of the professional public is that the displacement of children must be used as the last resort only after all other available opportunities are exhausted. For this reason, intensive measures of support for parents and families at risk are envisaged. Only if all these measures do not give the desired results; children are moved from their families to foster families or homes. Also, measures are reflected in the transformation, modernization and improvement of living conditions in homes, which should turn into modern centers for children and youngs.

As problem in the implementation of positive legal norms and problems in the practical application of these, it was determined the formation of waiting list for the service of accommodation in the retirement home. The current capacity of these facilities is not at a satisfactory level, nor is the equipment level. According to positive legal solutions, it is necessary to open public procurement for accommodation services in circumstances where needs cannot be fulfilled by engaging public capacities. The public procurement procedure involves preliminary assessment of the scope and territorial distribution of needs. As the service user has the right to choose the home in which he or she will reside, such legal solutions contribute to inappropriate allocation of funds and the inability to respond adequately to the demand. Instead of such ineffective solution, the new measures envisage the possibility of creating a functional network of authorized accommodation service providers that would provide services under the conditions prescribed by the line ministry. Users would also be able to use the service at home without waiting and forming waiting list, in better existential conditions, regardless of the fact that the hosts would have different founders. This would build a homogenous system of homes in the country, which would provide services in accordance with the needs of the users, using adequate resources and capacities under equal circumstances, regardless of who is the home founder. Also, the possibility of bringing users in the unequal position would be avoided.

In order to provide social services in a timely manner, it is necessary to have an up-to-date database. According to the positive Law on Social Protection, the database includes records and documentation, with the legislator paying very little attention to this important element. In the framework of providing social protection to citizens, various complex procedures for recognizing the rights of social welfare beneficiaries are firstly conducted, different types of support are decided upon, and strictly confidential personal data bases for users and related parties are being kept. Amendments to the present Law specify the registers and records that are kept and define their content and manner of conduct. Also, a central informational system of social protection is introduced, it unifies 
all existing registers into one single base, providing the basis of efficient supervision. Compliance with the provisions of the Law on Personal Data Protection is made and allows all data to be malnourished in one document, raising the level of work efficiency and data management. At the end of each calendar year, the Annual Social Security Report would be submitted, with data from the central information system.

Novelty in the proposed changes is also reflected in the changes of the status and position of social welfare beneficiaries. Particularly, concerning working-minded users, which are long-time beneficiaries of social protection services. With them is made the so-called " individual activation plan, with the aim of helping them to integrate in the labor market and taking responsibility for satisfying the their personal and family needs. The practice that was applied before the proposed changes were made, did not give the desired results because the activation plans were not precise, the procedure was not clearly defined, nor was the responsibility of those persons who took part in the activation.

The modern social welfare center must have highly qualified and competent personnel, which in every situation and circumstances know how to provide quality and conscientious support to those who are of particular importance. Therefore, the proper selection of personnel must be carried out exclusively according to the professional criteria of knowledge and experience in the field of social policy. The proposed amendments envisage the strengthening of the role of the Ethics Committee, especially in the segment of competencies and entrusted tasks, as well as the extent of professional responsibility imposed by this body. Also, in the social policy segment in the Republic of Serbia, the Republic Institute for Social Protection plays an important role. It conducts development, advisory and research activities and professional support activities, through the accreditation of training and social protection programs. Institute performs these tasks in continuity, and the proposed changes, also, extend the scope of activities of the Institute to external supervision in the preparation of methodological instructions and the preparation of the Annual Report on Social Protection, including the collection and processing of data. The proposed competencies of the Institute also include the harmonization of the social protection system at all levels, ranging from the central, provincial, city and local, as well as to the non-governmental sector. Also, the amendment of the positive law envisages the establishment of the new body, the National Institute for Social Protection.

Very important issue is the development of the Social Services Delivery Program. For the first time, the accreditation of the Program is announced and determined by the positive Law on Social Assistance, however without specific regulation, so that these provisions of the Law were not applied. The program includes activities meeting specific needs of users in the context of giving certain rights or goods and reduction and minimizing adverse effects in order to integrate users, as equal individuals, into the community. The fact that such important segment was not well defined by the positive Law has contributed to the reduction of the intensity of the promotion of professional work and contributed to the disabling the professional supervision of the work of these bodies.

As it has already been pointed out on several occasions, the amendments to the Law on Social Assistance have done lot to improve the quality of providing social services to beneficiaries, as well as in the raising the aspect of control in the work of 
professional services and individuals. The reason for the tightening of control should be sought in the deconcentrated organization of social protection at the administrative districts level, which is very uneven and have no precise form. Therefore, the proposed measures only strive to balance and guarantee the quality of their work. The external supervision, according to the given proposal, would represent a deconcentrated form of professional support for workers, organizations and bodies participating in social protection, would contribute to the improvement of the provision of services and the application of social protection measures and achievement of maximum. This measure would increase the level of co-operation within the social protection sector itself, which would ultimately improve the quality and efficiency of work. Also, in addition to external audit, inspectional supervision of professional work in the social protection bodies is introduced, which is realised in accordance with the provisions regulating the issue of supervision over the work of state administration bodies. The positive Law does not elaborate in detail the issue of the responsibility of supervised entities in the case of detecting errors in the implementation of supervision, as well as with the implementation of supervision and the procedure of inspection supervision.

\section{Organization of the Centers for Social Work}

In the current practice, social welfare beneficiaries could only address Social Rights Centers for their rights, their determination and realization. They decide on exercising the right to material security, exercising the right to allowance for assistance and care of another person, exercising the right to the training for work, exercising the right to accommodation in social care institution, exercising the right to accommodate adult in another family, foster care, guarding, determining and changing the personal name of minor, measures of preventive supervision over the exercise of parental rights and measures of corrective supervision over the exercise of parental rights.

In addition to the original, the Center for Social Work also performs entrusted tasks in the sense of exercising public authority, such as the establishment of mediation in family relations, participation in litigation procedures in relation to minors in the context of the delivery of findings and expert opinions, especially in lawsuits for the deprivation of parental rights, submits opinions on the validity of the measures for protection against domestic violence at the request of the competent prosecutor's office, provides assistance in obtaining relevant evidence during the civil or other court proceedings, conducts procedure for assessing the general suitability of the foster parent, adoptive parent or guardian, performs inventory and assessment of the property of the person under guardianship, cooperates with the competent authorities in the selection and application of educational orders, mediates between the juvenile perpetrator of the criminal offense and the victim, submits reports to the prosecution and juvenile judge on the fulfillment of educational orders, in the proceedings against the juvenile person and prepares questions and proposals to the persons who carry out these actions, it submits to the court opinions on the facts concerning the age of the juvenile perpetrator, his maturity, the environment and the circumstances in which he lives and other circumstances of his / her behavior the main hearing in the criminal procedure against the minor, informs the court about the escape and the inaccessibility of the juvenile perpetrator of the criminal offense, is committed 
to the execution of educational measures of special obligations, checks the execution of educational measures of enhanced supervision by the parent, adoptive parent or guardian, checks the execution of the educational measure of the enhanced supervision in the other family, carries out measure of intensified supervision by the guardianship authority, in particular taking care of the education of the juvenile, his employment and dispossession from the environment that is detrimental for him, taking care of the enforcement of the educational measure of increased supervision with the obligation of daily living in the institution for upbringing and education of minors, shall submit to the competent authorities report on the educational measures taken, propose to the court the decision on the costs of the execution of educational measures and initiate court proceedings in cases when the Law authorizes it (Šarkić \& Počuča, 2013, p. 155-172).

The work of the centers for social work must be public and accessible to all persons under equal conditions in order to avoid any form of discrimination in the social welfare right exercising. Centers must act preventively, through the development of programs that meet the individual and collective needs of citizens and suppress social problems in a local community. Preventive programs are designed to address specific categories of population and their current problems. They can include individuals, families with problems, marginalized social groups with the goal of their training in community life, education and parental training. The main task of the CSW program is to prevent the emergence of social problems such as family violence, youth offenses and the consumption of psychoactive substances. Programs should work on developing community volunteering and fostering civic awareness and accountability in order to better and more effectively identify social problems in the community (Đorđević et al., 1978, p. 284).

Regarding the organization of the centers for social work itself, it is aimed at the absolute professionalization of work in the centers, which would be performed by highly qualified personnel with special knowledge and sensitivity towards the socially vulnerable categories of the population, which predominantly occur in the role of the users of their services. The user is at the center of attention of the Center for Social Work, its condition and its real needs. It is the goal of the users to incorporate themselves more actively into the process of protection, decision-making process and the process of meeting their own needs. The Center for Social Work must be efficient and economical with responsible management business and human resources. The Center must coordinate with local communities in order to implement programs and activities. When it comes to the internal organization of the centers for social work, it starts from the scope of work, the establishment of the system of responsibility, the human resources management with an adequate evaluation of the professional work. In centers where less than ten employees work, the jobs are organized within one organizational unit. If the center works in the area of several municipalities, then special departments for each municipality can be formed separately. Otherwise, the basic organizational units in the Center for Social Work are: 1) the Children and Youth Protection Service, 2) the Adult and Old Care Service, 3) the Legal Affairs Service, and 4) Department for financial, administrative and technical matters. In addition to these basic ones, the Reception and Planning and Development Service can still function.

The head of the Center for Social Work is the director, who is responsible for the legality of the work of the center, the respect of professional standards in work, 
the internal and external coordination, the planning, the organizing and the controlling the work of the employees. Heads of organizational units of the centre provide: 1) the internal coordination and organization, 2) the plan and manage the scope of work, 3) respect the standards of professional work, 4) respect the legality of work, and 5) the respect of deadlines and procedures. The Head of the departments of centre is authorized: 1) to allocate and organize professional workers within the department, 2) to provide administrative support, spatial and technical conditions for work, 3) to perform control of timeliness and compliance with deadlines during the conduct, 4) keeping records and working with confidential user documentation, 5) to distribut items according to established procedures and criteria, with special care for the equal burden on all employees and rational use of working hours (Milovanović, 2009, p. 22-34).

In addition to directors and managers of organizational units, supervisors have a very important role in the internal organization of the Center for Social Work. They ensure compliance with the standards of professional work with the aim of ensuring the quality of services. Supervisors direct, train and evaluate the development of professional competencies of case-managers, so-called managers, while achieving optimal effects and meeting user needs. Supervisor has task to support case managers by organizing supervisory process at all stages of work. The supervisor has the authority: 1) to ensure the protection of the best interests of users organizes and realizes supervision in at all stages of the proceedings, 2) to inform managers of the unprofessional, incompetent and unlawful conduct of the case manager, and 3) to compile annual reports on the progress of the case manager and other professional workers (Polić, 2016, p. 66-71).

\section{Conclusion}

The Republic of Serbia is a country that traditionally stands on the point of view of strict respect for and respect for human rights. In this regard, social rights are also strictly respected. Serbia actively promotes social cohesion through: 1) the exercising the right to an adequate level of social protection, 2) the encouraging employment, further training and respecting the personality and integrity of workers, 3) the protecting the most vulnerable social categories, 4) the creating equal opportunities for all citizens, and 4) the prohibiting social discrimination. Although various endogenous and exogenous processes and events have contributed to social imbalances in Serbian society, Serbia can boast of the fact that it is a socially responsible state. The disturbance of the social balance was due to major changes in the domain of politics and economy, as well as demographic trends. As a consequence, these changes have led to: 1) the increasing of unemployment and poverty rate, 2) the increasing of high social segregation, 3) the increasing of levels of crime, and the vulnerability of personal security and security of personal property, especially the vulnerability of socially vulnerable categories, such as children and the old. Therefore, these societal challenges require an adequate response of the competent institutions, for which it is necessary to adopt appropriate legal frameworks. These new circumstances need to be introduced under the appropriate legal norms, that would effectively solve these problems or provide a mechanism for their resolution. This means the activation of citizens that, due to all these negative tendencies, went into a passive attitude and attitude towards society and social changes through: 1) 
the activating and raising the efficiency of the social protection system, 2) the integrating of the non-governmental sector into the social protection sector, and 3) the reducting of the level of bureaucracy and increase the level of professionalization of public social institutions.

Since the amending the positive Law on Social Protection is the current issue, the measures that were proposed in respective amendments and proposals of the Law on Social Protection were analyzed, with a review of positive legal solutions, as well as the potential effects that could be achieved by adopting the proposed changes. All changes should enable that the social protection in the Republic of Serbia is raised to a higher level, and the position of the user is brought to an adequate place, respecting his personality and integrity. On the other hand, one of the major innovations is certainly a social activation of social assistance beneficiaries, which in practice means that each user will be engaged in work, according to his abilities and ability to work. This novelty is not in an antagonism with the basic goal of social protection - the material support and the provision of social care services, because the working engagement of social welfare beneficiaries only stimulates their working capacity and performs vocational and professional training. So, although disputed, this novelty cannot be detrimental to the users, because it gives them multiple opportunities, through job training, through social integration.

The social protection system must be efficient and must meet the needs of various strata of socially vulnerable categories, such as: children, young people, people with disabilities, single parents and the elderly. These strata of socially vulnerable categories are characterized poverty and crisis that prevent and disable them in everyday life, vocational training, family formation and the resolution of existential issues. For this reason, the role of the centers for social work is primarily reflected in the fact that these people are saved in order to they did not to go to the social margin and use some unlawful form of satisfying their existential needs. That is why it is important to constantly modernize the work of social welfare institutions, keep up with the new tendencies and needs of the beneficiaries, decentralize social protection services and introduce new services with the increase in the volume and quality of the existing ones. In every society, even our priority issue should be the reduction of poverty and the improvement of the quality of social protection, with the rational allocation of capacities according to the territorial principle. Modern measures of social protection are achieved by raising the quality of life of socially vulnerable categories of the population. It is therefore crucial to adopt pre-existing amendments and supplements to the positive law, as well as the correct implementation of new measures in practice. Applying new legal solutions should be monitored and evaluated for their effectiveness, both from the aspect of theory and practice.

\section{References}

Brković, R. (2014). Usluge socijalne zaštite. Kragujevac, Pravni fakultet.

Brković, R. (2015). Socijalno preduzetništvo, trenutna situacija i mogućnosti za razvoj u Srbiji i drugim zemljama bivše Jugoslavije. Pravna reč, 12 (42): 23-35.

Đorđević, M., Obretković, M., \& Popović, R. (1978). Centar za socijalni rad kao organ starateljstva. Beograd, Institut društvenih nauka. 
Milovanović, B. (2009). Organizacija i sistematizacija rada u centrima za soocijalni rad. Socijalna politika, 2(2):22-34.

Nedeljković, N. (2017). Altruizam i motivacija za hraniteljstvo. Filozofski fakultet, Beograd.

Polić, S. (2016). Uticaj supervizije na profesionalni razvoj voditelja slučaja u centru za socijalni rad. Beograd, Fakultet političkih nauka.

Radovanović, J. (2015). Socijalna pomoć sao sistem socijalne sigurnosti. Niš, Pravni fakultet.

Šarkić, N., \& Počuča, M. (2013). Ovlašćenja centara za socijalni rad u porodično pravnoj materiji po odredbama Zakona o vanparničnom postupku. Pravni život, 62 (564): 155-172.

Vuković, D. (1998). Karakter i ciljevi socijalne zaštite u zemljama EU. Socijalna politika i socijalni rad, 34(2): 110-132.

Nacrt Zakona o izmenama i dopunama Zakona o socijalnoj zaštiti Republike Srbije.

Pravilnik o organizaciji, normama i standardima rada centara za socijalni rad (“Službeni glasnik RS” br. 59/2008, 37/2010, 39/2011 i 1/2012).

Zakon o doprinosima za obavezno socijalno osiguranje ("Službeni glasnik RS" broj 84/2004, 61/2005, 62/2006, 5/2009, 52/2011, 101/2011, 7/2012, 8/2013, 47/2013), 108/2013, 6/2014, 57/2014, 68/2014, 5/2015, 112/2015, 5/2016, $7 / 2017,113 / 2017,7 / 2018$ и 95/2018)

Zakon o finansijskoj podršci porodicama sa decom ("Službeni glasnik RS” broj 113/2017 i 50/2018)

Zakon o socijalnoj pomoći (“Službeni glasnik RS” broj 24/2011) 